Prepared in cooperation with the Bureau of Land Management

\title{
Streamflow Gains and Losses in New Fork and Green Rivers, Upstream from Fontenelle Reservoir, Wyoming, October 2015
}

Scientific Investigations Report 2019-5081 
Cover. Collecting concurrent measurements at site NF5, New Fork River below East Fork River, near New Fork, Wyoming, October 21, 2015. Photograph by Jerrod D. Wheeler.

Back cover. Staff and equipment needed to collect streamflow measurements for the streamflow gain and loss study of the New Fork and Green Rivers. Photograph taken at site NF8, New Fork River near Big Piney, Wyoming, October 22, 2015. Photograph by J. Brooks Stephens. 


\section{Streamflow Gains and Losses in New Fork and Green Rivers, Upstream from Fontenelle Reservoir, Wyoming, October 2015}

By Cheryl A. Eddy-Miller, Seth L. Davidson, Jerrod D. Wheeler, Sarah J. Davis, J. Brooks Stephens, and James R. Campbell

Prepared in cooperation with the Bureau of Land Management

Scientific Investigations Report 2019-5081 


\title{
U.S. Department of the Interior DAVID BERNHARDT, Secretary
}

\author{
U.S. Geological Survey \\ James F. Reilly II, Director
}

U.S. Geological Survey, Reston, Virginia: 2019

For more information on the USGS - the Federal source for science about the Earth, its natural and living resources, natural hazards, and the environment-visit https://www.usgs.gov or call 1-888-ASK-USGS.

For an overview of USGS information products, including maps, imagery, and publications, visit https://store.usgs.gov.

Any use of trade, firm, or product names is for descriptive purposes only and does not imply endorsement by the U.S. Government.

Although this information product, for the most part, is in the public domain, it also may contain copyrighted materials as noted in the text. Permission to reproduce copyrighted items must be secured from the copyright owner.

Suggested citation:

Eddy-Miller, C.A., Davidson, S.L., Wheeler, J.D., Davis, S.J., Stephens, J.B., and Campbell, J.C., 2019, Streamflow gains and losses in New Fork and Green Rivers, upstream from Fontenelle Reservoir, Wyoming, October 2015: U.S. Geological Survey Scientific Investigations Report 2019-5081, 15 p., https://doi.org/10.3133/sir20195081.

ISSN 2328-0328 (online) 


\section{Acknowledgments}

The authors gratefully acknowledge the assistance of local landowners and State and Federal agencies, without whom streamflow at the desired sites could not have been measured. Kathy

Raper, Sublette County Conservation District, was instrumental in assisting with contacting landowners. 



\section{Contents}

Acknowledgments ……...................................................................................................................

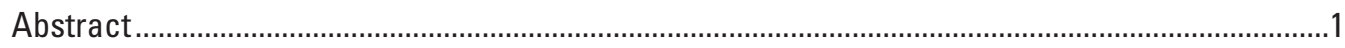

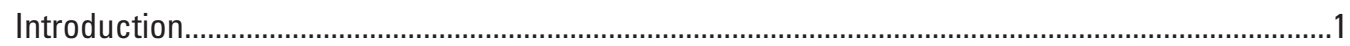

Description of Study Area ..................................................................................................

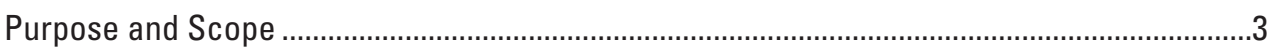

Streamflow Measurements in the New Fork and Green Rivers, Wyoming, October 2015...............3

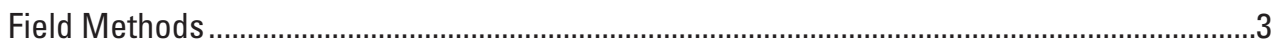

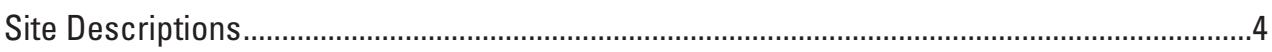

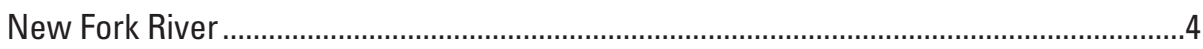

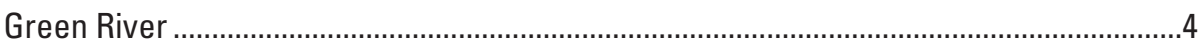

Synoptic Streamflow Measurements and Relations to Historical Streamflow.........................7

Hydrologic Conditions During Synoptic Streamflow Measurements .................................7

New Fork River ...................................................................................................................

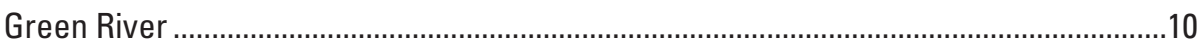

Estimated Streamflow Gains and Losses in Selected River Reaches of the New Fork

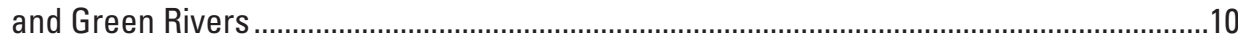

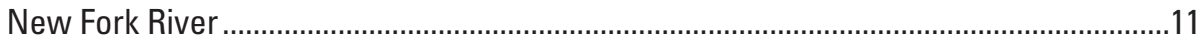

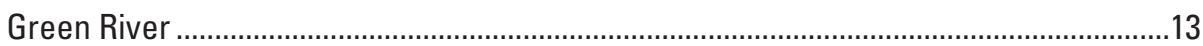

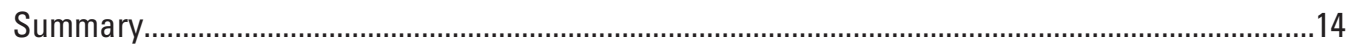

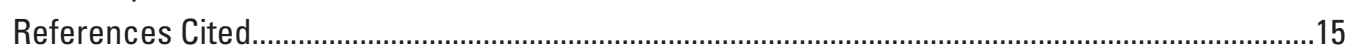

\section{Figures}

1. Map showing location of New Fork and Green Rivers in the upper Green River Basin and sites used for the synoptic study, Wyoming, October 2015 .............................2

2. Map showing location of synoptic sites and reaches on New Fork and Green

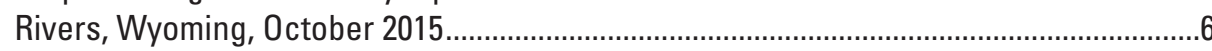

3. Graph showing changes in stage, compared to an arbitrary datum, for streamgages 09205000 (site NF8, New Fork River near Big Piney), 09188500 (site Gr1, Green River at Warren Bridge), and 09209400 (site Gr8, Green River near La Barge) and measurement times of synoptic sampling, Wyoming, October 2015 ........8

4. Graph showing mean streamflow during October 19-22, 2015, at sites used in New Fork River synoptic sampling, and median and range of streamflows on October 20 at co-located sites with historical data, Wyoming

5. Graph showing mean streamflow during October 19-22, 2015, at sites used in Green River synoptic sampling, and median and range of streamflows on October 20 (or the month of 0 ctober for site $\mathrm{Gr} 4$ ) at co-located sites with historical data, Wyoming.

6. Graph showing mean streamflow measured during October 19-22, 2015, synoptic measurements and summation of measured upstream inflows, New Fork River, Wyoming.

7. Graph showing mean of mean daily streamflow for the period of record at streamgages 09205000 (site NF8, New Fork River near Big Piney), 09188500 (site Gr1, Green River at Warren Bridge), and 09209400 (site Gr8, Green River near La Barge), Wyoming 
8. Graph showing mean streamflow measured during 0ctober 19-22, 2015, synoptic measurements and summation of measured upstream inflows, Green River,

Wyoming.

\section{Tables}

1. Description and location of streamflow measurement sites and associated reaches, Wyoming, October 2015

2. Selected streamflow measurements collected on New Fork and Green Rivers, Wyoming, October 19-22, 2015.

3. Mean streamflow measured, estimated errors, and streamflow gains and (or) losses estimated for New Fork River reaches, Wyoming, October 19-22, 2015

4. Mean streamflow measured, estimated errors, and gain or loss calculations for Green River reaches, Wyoming, October 19-22, 2015.

\section{Conversion Factors}

U.S. customary units to International System of Units

\begin{tabular}{|c|c|c|}
\hline Multiply & By & To obtain \\
\hline \multicolumn{3}{|c|}{ Length } \\
\hline inch (in.) & 2.54 & centimeter $(\mathrm{cm})$ \\
\hline foot $(\mathrm{ft})$ & 0.3048 & meter $(\mathrm{m})$ \\
\hline mile (mi) & 1.609 & kilometer (km) \\
\hline \multicolumn{3}{|c|}{ Area } \\
\hline square mile $\left(\mathrm{mi}^{2}\right)$ & 259.0 & hectare (ha) \\
\hline \multicolumn{3}{|c|}{ Flow rate } \\
\hline cubic foot per second $\left(\mathrm{ft}^{3} / \mathrm{s}\right)$ & 0.02832 & cubic meter per second $\left(\mathrm{m}^{3} / \mathrm{s}\right)$ \\
\hline
\end{tabular}

\section{Datum}

Vertical coordinate information is referenced to the North American Vertical Datum of 1988 (NAVD 88).

Horizontal coordinate information is referenced to the North American Datum of 1983 (NAD 83).

Elevation, as used in this report, refers to distance above the vertical datum. 


\title{
Streamflow Gains and Losses in New Fork and Green Rivers, Upstream from Fontenelle Reservoir, Wyoming, October 2015
}

\author{
By Cheryl A. Eddy-Miller, Seth L. Davidson, Jerrod D. Wheeler, Sarah J. Davis, J. Brooks Stephens, and \\ James R. Campbell
}

\section{Abstract}

The Wyoming Landscape Conservation Initiative is a program created to implement a long-term, science-based program of assessing natural resources while facilitating responsible energy and other development and does studies in much of southwestern Wyoming, including all or parts of Lincoln, Sublette, Fremont, Sweetwater, and Carbon Counties. A synoptic study was completed by the U.S. Geological Survey as part of ongoing contributions to the Wyoming Landscape Conservation Initiative to better understand the streamflow dynamics in the New Fork and Green Rivers in an area with historical, current, and future energy development.

Streamflow measurements were collected October 19-22, 2015, at 19 sites on the New Fork and Green Rivers in Wyoming to determine changes in streamflow and, where applicable, describe the inflow and outflow of groundwater. Streamflow in the New Fork River generally increased from 50 cubic feet per second $\left(\mathrm{ft}^{3} / \mathrm{s}\right)$ at the most upstream site near Pinedale, Wyoming, to $350 \mathrm{ft}^{3} / \mathrm{s}$ at the mouth of the river. Streamflow in the Green River generally increased downstream from $250 \mathrm{ft}^{3} / \mathrm{s}$ at the most upstream site at Warren Bridge to around $800 \mathrm{ft}^{3} / \mathrm{s}$ at the most downstream site near La Barge, Wyo., upstream from Fontenelle Reservoir.

Estimated streamflow gains and losses were calculated for five reaches on the New Fork River. Four of the five reaches on the New Fork River had a change greater than the associated measurement error and were gaining reaches; the reach with the largest gain was the most upstream reach. One reach, the most downstream reach, had a calculated change in streamflow less than the associated measurement error.

Estimated streamflow gains and losses were calculated for four reaches on the Green River. One reach was determined to be a gaining reach, one was a losing reach, and two reaches had changes less than the associated measurement error.

Comparing the annual streamflow hydrographs for three long-term streamgages likely showed the effects of applying irrigation water to the upstream areas of land draining to the Green and New Fork Rivers. Streamflows in the
New Fork River near Big Piney and the Green River near La Barge, Wyo., are sustained later in the season compared to the upstream site of Green River at Warren Bridge, which has few diversions and minimal irrigation.

\section{Introduction}

The Wyoming Landscape Conservation Initiative is a program created to "implement a long-term, science-based program of assessing, conserving, and enhancing fish and wildlife habitats while facilitating responsible energy and other development through local collaboration and partnerships" (Bowen and others, 2014, p. 2). The Wyoming Landscape Conservation Initiative study area includes much of southwestern Wyoming, including all or parts of Lincoln, Sublette, Fremont, Sweetwater, and Carbon Counties (fig. 1). To better understand the streamflow dynamics in the New Fork and Green Rivers, which flow through an area with historical, current, and future energy development, a synoptic streamflow measurement study was completed by the U.S. Geological Survey in cooperation with the Bureau of Land Management as part of ongoing contributions to the Wyoming Landscape Conservation Initiative. Streamflow measurements were collected October 19-22, 2015, and were used to estimate gains and losses along selected reaches in both rivers. Measuring streamflow at sites in a synoptic or snapshot manner allows the change of streamflow over the reach to be determined, and gains and losses to be quantified. Streamflow measurements collected during a synoptic study are often referred to as a seepage run because they describe the exchange of stream water with the local groundwater. During October 19-22, 2015, streamflow measurements were collected at 9 sites on the New Fork River and a tributary (Pole Creek) and 10 sites on the Green River and a tributary (La Barge Creek).

The goal of a synoptic streamflow study or seepage run is to determine which sections of the stream gain or lose water over that respective reach. Synoptic streamflow measurements are made during the hydrologic conditions when base flows are sustaining the river, after snowmelt runoff has subsided, 


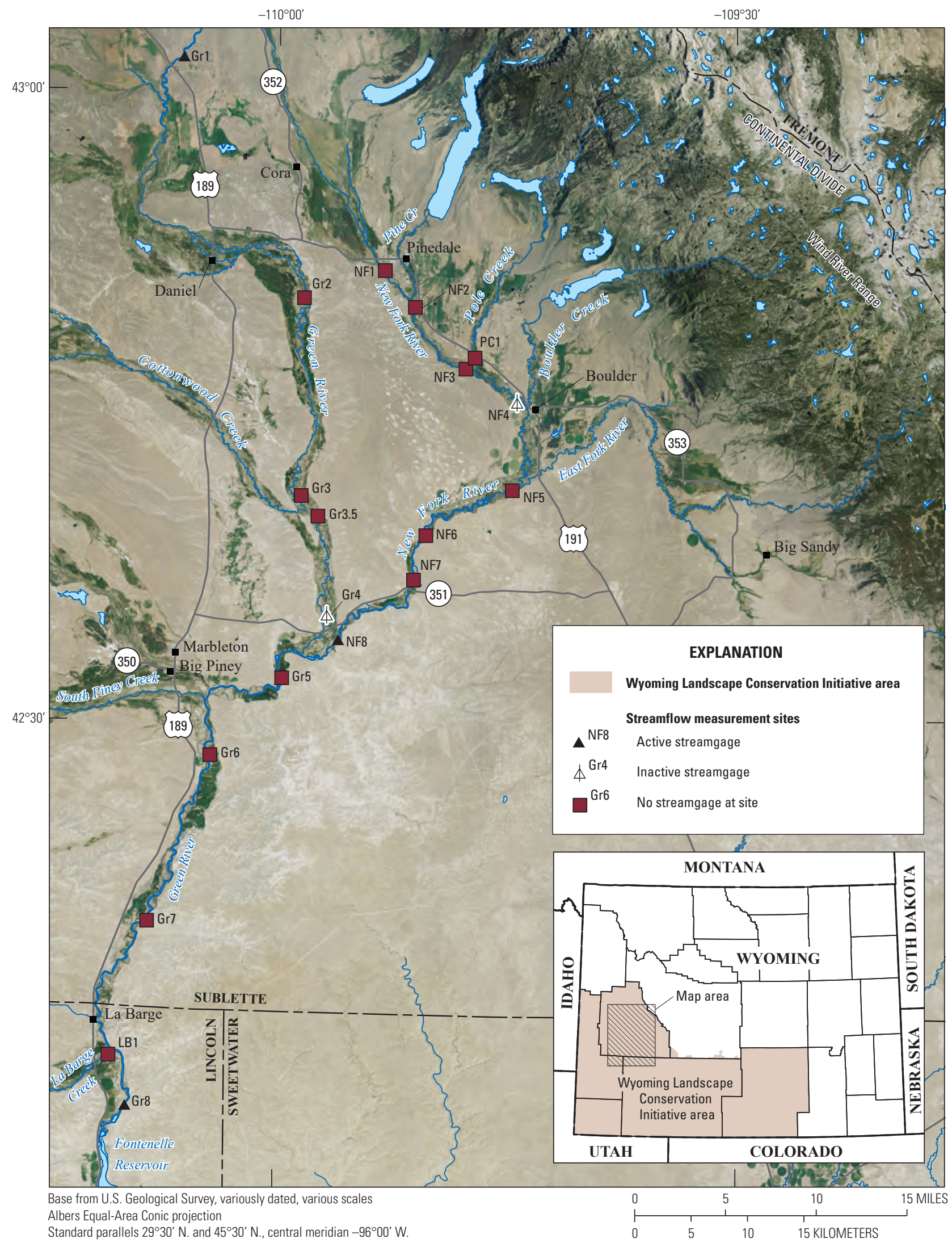

Horizontal coordinate information is referenced to the

North American Datum of 1983 (NAD 83)

Figure 1. Location of New Fork and Green Rivers in the upper Green River Basin and sites used for the synoptic study, Wyoming, October 2015. 
and when, ideally, no precipitation (hence no runoff) events occur. Additionally, inflows and outflows from tributaries, irrigation, and other activities need to be measured or minimized. In this study area, the optimal time to complete a synoptic streamflow study is typically in the fall between the end of irrigation season and while the rivers are still ice free, usually a period of about 4 weeks.

\section{Description of Study Area}

The New Fork and Green Rivers originate in the Wind River Range with snowmelt as the primary water source. Both rivers are perennial from their headwaters, flowing through high elevation lakes before entering the basin proper. The rivers generally flow south and meet about halfway through the study area (fig. 1). The most upstream study reaches of the New Fork and Green Rivers are within more confined channels below reaches that flow from the mountains and moraines and into the basin. The farthest downstream site on the New Fork River is near its mouth (site NF8; fig. 1). After the confluence with the New Fork River, the Green River continues flowing south, and the farthest downstream site on the Green River is site Gr8, Green River near La Barge, Wyoming. Site Gr8 is immediately upstream from the Fontenelle Reservoir; the reservoir is just south of the study area. The drainage area is about 3,910 square miles at site Gr8, the Green River near La Barge streamgage. In general, land-surface elevation within the upper Green River Basin ranges from more than 12,000 feet (ft) at the continental divide in the northern part of the study area to $6,530 \mathrm{ft}$ at site $\mathrm{Gr} 8$ in the southern part of the study area.

Many irrigation diversions and return flows exist on the New Fork and Green Rivers. Unused and infiltrated irrigation water returns to both rivers through discrete canals, dispersed surface expressions, and movement through the subsurface. In some areas, the dispersed flow makes it nearly impossible to capture all streamflow in a single cross section, making several sections of both rivers unsuitable for a synoptic study.

Vegetation is generally moderately sparse along the rivers and consists of cottonwood, willow, sedges, grasses, and sage, predominantly in the riparian zone. Surface geology in the extreme upper part of the basin consists of Precambrian granites, gneisses, and migmatites associated with the Wind River uplift, along with sections of Cretaceous sandstones and limestones (Love and Christiansen, 1985). The surficial geology in most of the remainder of the study area consists of Tertiary shales, sandstones, siltstones, claystones, and evaporites associated with the Green River Formation (Bartos and others, 2015). Major tributaries of the New Fork River within the study area are Pine Creek, Pole Creek, Boulder Creek, and the East Fork River. Major tributaries of the Green River within the study area are Cottonwood Creek, South Piney Creek, and La Barge Creek.

\section{Purpose and Scope}

The purpose of this report is to describe estimated streamflow gains and losses along the New Fork and Green Rivers upstream from Fontenelle Reservoir (fig. 1) during October 19-22, 2015. Changes in streamflow downstream, the October 2015 hydrologic conditions, and how data collected in October 2015 compare to historical data are also described.

\section{Streamflow Measurements in the New Fork and Green Rivers, Wyoming, October 2015}

A total of 46 streamflow measurements were made during October 19-22, 2015, to better understand the streamflow dynamics in the New Fork and Green Rivers. Some sites were visited more than 1 day and had two sets of streamflow measurements. Only 1 day's measurements were used for the study. All data, however, are available in the National Water Information System at https://waterdata.usgs.gov/wy/nwis/sw (U.S. Geological Survey, 2019). Five reaches on the New Fork River and four reaches on the Green River were selected to describe streamflow gains and losses, which can be used to understand the interaction of the stream with near-stream groundwater.

\section{Field Methods}

All streamflow measurement methods followed standard U.S. Geological Survey discharge (streamflow) measurement protocols (Rantz and others, 1982; Nolan and Shields, 2000). Acoustic Doppler velocity meters and acoustic Doppler current profiler meters were used exclusively because of their ability to provide high-resolution velocity data and their suitability in shallow stream environments. During the time it took to measure streamflow at a site, typically around 1 hour, fluctuations in stage were monitored at each measurement location either by using existing staff gages or by setting up temporary reference marks and measuring to the water surface. At all sites, stage did not substantially change during each set of streamflow measurements at individual sites, and observed maximum fluctuations were plus or minus $0.02 \mathrm{ft}$.

Cross-section locations were selected where possible to maximize favorable flow conditions (for example, uniform cross section, perpendicular flow, and nonturbulent flow) and minimize potential measurement errors from factors such as heavy aquatic plant growth, uneven streambeds, and irregular velocity profiles. Some cross-section locations were limited by stream access. 
At least two streamflow measurements were performed during each visit, either concurrently or sequentially, to increase the accuracy of the streamflow value. If the difference between the two streamflow measurements was greater than 5 percent, at least one additional measurement was performed to improve accuracy.

\section{Site Descriptions}

In total, 19 sites were selected on the New Fork and Green Rivers (table 1; fig. 2) to describe streamflow changes. These sites also were used to quantify the upstream and downstream streamflow of each of the nine reaches (fig. 2).

During site selection, priority was given to sites with either inactive or active streamgages. When permission for access was received, the historical sites were selected. If historical sites were not available, new sites were established at locations to define specific reaches. Two streamgages (one historical and one current) on the New Fork River were selected as synoptic measurement sites: NF4, New Fork River near Boulder, Wyo. (data were collected during 1914-68) and NF8, New Fork River near Big Piney, Wyo. (data were collected 1953 to present [2019]). Two currently operated streamgages on the Green River were used as synoptic sites: Gr1, Green River at Warren Bridge, near Daniel, Wyo. (data were collected 1931 to present [2019]) and Gr8, Green River near La Barge, Wyo. (data were collected 1953 to present [2019]). In addition to these two Green River streamgages, site Gr4, where monthly and then quarterly water-quality samples were collected from 1967 to 1984, was selected because streamflow measurements made during the water-quality sampling could be used to describe historical flows.

\section{New Fork River}

Streamflow in the New Fork River was measured at eight main-stem sites from site NF1 near Pinedale downstream to site NF8 near the confluence with the Green River (fig. 2).

Site NF1 was west of Pinedale in the most upstream part in the valley where streamflow that had dispersed across the valley begins to become more channelized. Site NF2 was a short distance downstream from the confluence of the New Fork River with Pine Creek and was the upstream site of reach 1. Pole Creek (site PC1) was the only measured tributary in reach 1 and was measured near its confluence with the New Fork River. Site NF3 was the downstream site of reach 1 and the upstream site of reach 2.

Site NF4 was at a historical streamgage and was the downstream site of reach 2. Downstream from site NF4, inflows include Boulder Creek, the East Fork River, numerous irrigation returns, and surface gains of water from natural or applied water sources, which made quantification of inflows and outflows unfeasible. Therefore, reaches 2 and 3 are not connected, and reach 3 begins at site NF5, just downstream from the confluence with the East Fork River.

Site NF6 was where topography creates a confined channel and is the downstream site of reach 3 and the upstream site of reach 4. Site NF7 was selected at a fishing access point to provide information and is the downstream site of reach 4 and upstream site of reach 5. Site NF8 is upstream from the confluence with the Green River and is the most downstream site measured on the New Fork River and is the downstream site for reach 5 .

\section{Green River}

The studied section of the Green River is longer than the studied section of the New Fork River (fig. 2). Because of partner interest, time constraints, access to stream locations, tributaries, and numerous irrigation diversions and return flows, sites selected on the Green River tended to be farther apart from each other than sites selected on the New Fork River. Sites in the upper part of the study ( $\mathrm{Gr} 1$ and $\mathrm{Gr} 2$ ) are not used to define reaches because of the dispersed nature of the Green River in that area and were only used for describing changes in streamflow downstream, not to quantify streamflow gains or losses.

Site Gr1 was at the streamgage Green River at Warren Bridge. Downstream from Grl and in the area around Daniel, Wyo., several tributaries join the river and the river flows in a highly braided channel, and diversions for irrigation are common. Downstream site Gr2 was selected in an area where the main channel of the river is relatively confined.

Site Gr3 was on the Green River just upstream from the confluence with Cottonwood Creek and is the upstream site for reach 6. Sit Gr3.5 was on the Green River downstream from Cottonwood Creek. Because access to measure streamflow on Cottonwood Creek was not available, the difference of streamflow between Gr3 and Gr3.5 was used to calculate the contribution for Cottonwood Creek. Site Gr4 was where the river is confined to flow under Highway 351 and is the downstream site for reach 6 and the upstream site of reach 7 .

The downstream site in reach 7 , site Gr5, is in a topographic constriction. Streamflow at site Gr5 is an accumulation of flows in the upstream Green River, the New Fork River, and groundwater inflows from natural sources and irrigation infiltration.

Site Gr6 was downstream from the confluence with the South Piney Creek drainage and is the upstream site of reach 8. Site Gr7 was selected in a location where the channel is confined and no side channels were present and is the downstream site of reach 8 and the upstream site of reach 9 . Site Gr8 was the downstream site of reach 9 and is at the streamgage, Green River near La Barge, Wyo. Site LB1 was measured to quantify the input from La Barge Creek into reach 9 . 
Table 1. Description and location of streamflow measurement sites and associated reaches, Wyoming, 0ctober 2015.

[Station and site numbers in bold denote a current or historical U.S. Geological Survey streamgage or sampling site]

\begin{tabular}{|c|c|c|c|c|}
\hline $\begin{array}{l}\text { U.S. Geological Survey } \\
\text { station number }\end{array}$ & $\begin{array}{l}\text { Site number } \\
\text { (fig. 1) }\end{array}$ & Station description & Latitude $^{1}$ & Longitude $^{1}$ \\
\hline \multicolumn{5}{|c|}{ New Fork River sites } \\
\hline 425130109530801 & NF1 & New Fork River, above reach 1 & $42^{\circ} 51^{\prime} 30^{\prime \prime}$ & $-109^{\circ} 53^{\prime} 08^{\prime \prime}$ \\
\hline \multicolumn{5}{|c|}{ Reach 1} \\
\hline 424930109510101 & NF2 & New Fork River, upstream end of reach 1 & $42^{\circ} 49^{\prime} 31^{\prime \prime}$ & $-109^{\circ} 51^{\prime} 01^{\prime \prime}$ \\
\hline 424739109472001 & $\mathrm{PC} 1$ & Pole Creek, tributary to New Fork River & $42^{\circ} 47^{\prime} 39^{\prime \prime}$ & $-109^{\circ} 47^{\prime} 20^{\prime \prime}$ \\
\hline 424627109465201 & NF3 & New Fork River, downstream end of reach 1 & $42^{\circ} 46^{\prime} 27^{\prime \prime}$ & $-109^{\circ} 46^{\prime} 52^{\prime \prime}$ \\
\hline \multicolumn{5}{|c|}{ Reach 2} \\
\hline 424627109465201 & NF3 & New Fork River, upstream end of reach 2 & $42^{\circ} 46^{\prime} 27^{\prime \prime}$ & $-109^{\circ} 46^{\prime} 52^{\prime \prime}$ \\
\hline 09201000 & NF4 & New Fork River, downstream end of reach 2 & $42^{\circ} 45^{\prime} 01^{\prime \prime}$ & $-109^{\circ} 43^{\prime} 44^{\prime \prime}$ \\
\hline \multicolumn{5}{|c|}{ Reach 3} \\
\hline 424101109441701 & NF5 & New Fork River, upstream end of reach 3 & $42^{\circ} 41^{\prime} 01^{\prime \prime}$ & $-109^{\circ} 44^{\prime} 17^{\prime \prime}$ \\
\hline 423915109501001 & NF6 & New Fork River, downstream end of reach 3 & $42^{\circ} 39^{\prime} 15^{\prime \prime}$ & $-109^{\circ} 50^{\prime} 10^{\prime \prime}$ \\
\hline \multicolumn{5}{|c|}{ Reach 4} \\
\hline 423915109501001 & NF6 & New Fork River, upstream end of reach 4 & $42^{\circ} 39^{\prime} 15^{\prime \prime}$ & $-109^{\circ} 50^{\prime} 10^{\prime \prime}$ \\
\hline 423619109512001 & NF7 & New Fork River, downstream end of reach 4 & $42^{\circ} 36^{\prime} 19^{\prime \prime}$ & $-109^{\circ} 51^{\prime} 20^{\prime \prime}$ \\
\hline \multicolumn{5}{|c|}{ Reach 5} \\
\hline 423619109512001 & NF7 & New Fork River, upstream end of reach 5 & $42^{\circ} 36^{\prime} 19^{\prime \prime}$ & $-109^{\circ} 51 ' 20^{\prime \prime}$ \\
\hline 09205000 & NF8 & $\begin{array}{l}\text { New Fork River, downstream end of reach } 5 \text {, } \\
\text { currently active streamgage, New Fork River near } \\
\text { Big Piney }\end{array}$ & $42^{\circ} 34^{\prime} 02^{\prime \prime}$ & $-109^{\circ} 55^{\prime} 48^{\prime \prime}$ \\
\hline \multicolumn{5}{|c|}{ Green River sites } \\
\hline 09188500 & Gr1 & $\begin{array}{l}\text { Green River, above reach 6, currently active } \\
\text { streamgage, Green River at Warren Bridge near } \\
\text { Daniel }\end{array}$ & $43^{\circ} 01^{\prime} 10^{\prime \prime}$ & $-110^{\circ} 07^{\prime} 07^{\prime \prime}$ \\
\hline 424944109575401 & Gr2 & Green River, above reach 6 & $42^{\circ} 49^{\prime} 44^{\prime \prime}$ & $-109^{\circ} 57^{\prime} 54^{\prime \prime}$ \\
\hline \multicolumn{5}{|c|}{ Reach 6} \\
\hline 424008109580701 & Gr3 & Green River, upstream end of reach 6 & $42^{\circ} 40^{\prime} 08^{\prime \prime}$ & $-109^{\circ} 58^{\prime} 07^{\prime \prime}$ \\
\hline 423959109580701 & Gr3.5 & $\begin{array}{l}\text { Green River, below Cottonwood Creek, tributary to } \\
\text { Green River }\end{array}$ & $42^{\circ} 39^{\prime} 59^{\prime \prime}$ & $-109^{\circ} 58^{\prime} 07^{\prime \prime}$ \\
\hline 09192600 & Gr4 & Green River, downstream end of reach 6 & $42^{\circ} 34^{\prime} 14^{\prime \prime}$ & $-109^{\circ} 57^{\prime} 01^{\prime \prime}$ \\
\hline \multicolumn{5}{|c|}{ Reach 7} \\
\hline 09192600 & Gr4 & Green River, upstream end of reach 7 & $42^{\circ} 34^{\prime} 14^{\prime \prime}$ & $-109^{\circ} 57^{\prime} 01^{\prime \prime}$ \\
\hline 09205000 & NF8 & New Fork River, tributary to Green River & $42^{\circ} 34^{\prime} 02^{\prime \prime}$ & $-109^{\circ} 55^{\prime} 48^{\prime \prime}$ \\
\hline 423153109594301 & Gr5 & Green River, downstream end of reach 7 & $42^{\circ} 31^{\prime} 53^{\prime \prime}$ & $-109^{\circ} 59^{\prime} 46^{\prime \prime}$ \\
\hline \multicolumn{5}{|c|}{ Reach 8} \\
\hline 422729110044001 & Gr6 & Green River, upstream end of reach 8 & $42^{\circ} 27^{\prime} 29^{\prime \prime}$ & $-110^{\circ} 04^{\prime} 40^{\prime \prime}$ \\
\hline 421906110092501 & Gr7 & Green River, downstream end of reach 8 & $42^{\circ} 19^{\prime} 06^{\prime \prime}$ & $-110^{\circ} 09^{\prime} 25^{\prime \prime}$ \\
\hline \multicolumn{5}{|c|}{ Reach 9} \\
\hline 421906110092501 & Gr7 & Green River, upstream end of reach 9 & $42^{\circ} 19^{\prime} 06^{\prime \prime}$ & $-110^{\circ} 09^{\prime} 25^{\prime \prime}$ \\
\hline 421353110095301 & LB1 & La Barge Creek, tributary to Green River & $42^{\circ} 13^{\prime} 53^{\prime \prime}$ & $-110^{\circ} 09^{\prime} 53^{\prime \prime}$ \\
\hline 09209400 & Gr8 & $\begin{array}{l}\text { Green River, downstream end of reach } 9 \text { currently } \\
\text { active streamgage, Green River near La Barge }\end{array}$ & $42^{\circ} 11^{\prime} 34^{\prime \prime}$ & $-110^{\circ} 09^{\prime} 48^{\prime \prime}$ \\
\hline
\end{tabular}

${ }^{1}$ Latitude and longitude are referenced to the North American Datum of 1983. 


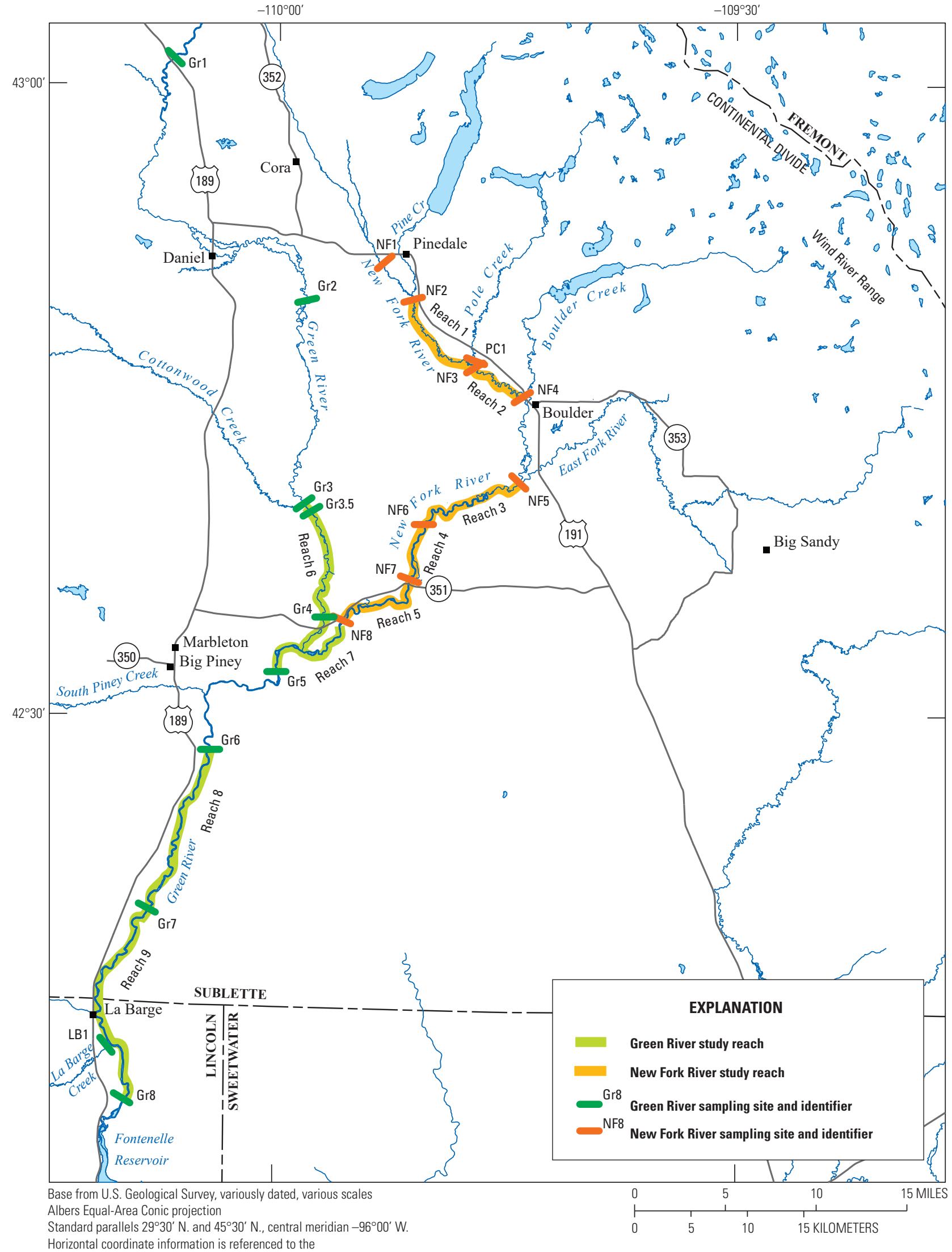

Horizontal coordinate information is referenced to the

North American Datum of 1983 (NAD 83)

Figure 2. Location of synoptic sites and reaches on New Fork and Green Rivers, Wyoming, October 2015. 


\section{Synoptic Streamflow Measurements and Relations to Historical Streamflow}

All streamflow measurements collected during the synoptic sampling event on the New Fork and Green Rivers are available in the National Water Information System at https://waterdata.usgs.gov/wy/nwis/sw (U.S. Geological Survey, 2019). Historical data from inactive streamgages, and historical and real-time data from active streamgages and miscellaneous measurements also can be found using the same link.

\section{Hydrologic Conditions During Synoptic Streamflow Measurements}

On October 19, 2015, a rainfall event occurred in the study area, with the largest precipitation near Pinedale, Wyo., and the nearby Wind River Range (fig. 1) where recorded rainfall was 0.38 inch (in.) at Pinedale, 0.30 in. at the New Fork streamgage (09205000), and 0.14 in. at the La Barge streamgage (09209400) (James Fahey, National Weather Service, written commun., October 30, 2015). The rainfall created a pulse of water that increased streamflow and raised the stage observed in the three active streamgages (sites NF8, Gr1, and Gr8; fig. 3). Because of the known attenuation and dispersement of the rainfall pulse, it was decided that most sites on Green River would be measured on October 20 when the Green River would likely be less affected by rainfall than the New Fork River. Additional measurements were collected on the Green River on October 21 and 22, but it was determined that the October 22 measurements were more affected by the rainfall than the October 20 measurements at the downstream sites, as can be seen by the sustained higher stage at the farthest downstream streamgage, Green River near La Barge (site Gr8). As noted on figure 3, while the stage of the Green River at both streamgages fluctuated during the day of October 20, the change during the time when all measurements were collected on the Green River was $0.01 \mathrm{ft}$ at Warren Bridge (site Gr1) and $0.02 \mathrm{ft}$ near La Barge (site Gr8). These stage changes equated to increases in streamflow of 3.7 and 20 cubic feet per second $\left(\mathrm{ft}^{3} / \mathrm{s}\right)$, respectively. The Green River sites had a maximum change from a base-flow stage of $0.06 \mathrm{ft}$ at Warren Bridge before the rainfall to $0.10 \mathrm{ft}$ at La Barge after the rainfall.

Streamflow in the New Fork River was measured on October 19 (at one site, NF1), just after the rainfall, and the rest of the sites were measured October 21-22. Data from the streamgage on the New Fork River near Big Piney (site NF8), which is the most downstream site on the New Fork River, showed the rainfall pulse peak mid-day on October 20, and the river began to recede afterward. The rainfall caused an increase in stage of $0.08 \mathrm{ft}$, which equated to an increase in streamflow of $50 \mathrm{ft}^{3} / \mathrm{s}$. It was assumed that the most upstream sites would return to base-flow conditions after the rain event more quickly than the downstream sites. Therefore, the measurements collected on October 22 were used instead of the October 21 measurements to calculate streamflow gain and loss at the four downstream sites. On October 22, the stage at the most downstream site on the New Fork River, NF8, was near base-flow levels at $0.04 \mathrm{ft}$ above the October 19 stage, compared to the maximum of $0.17 \mathrm{ft}$ above the base-flow stage on October 20.

The rainfall event on October 19 was not ideal for data collection and complicated data analyses; however, because of the feasibility of remobilizing a crew of six hydrographers in the short time when a synoptic survey can be completed, the measurements were collected during this time. Effects of the rain were mitigated as much as possible by repeating measurements at some sites in response to the pulse of rainfall. Rainfall creates higher streamflows and makes the relatively steady groundwater gains and losses a smaller percentage of the streamflow, which makes the gain and loss harder to detect. Although it was not ideal to have rainfall before measurements, the notation of reaches where calculated groundwater gains and losses indicate a flux greater than measurement error is considered accurate.

\section{New Fork River}

Streamflow in the New Fork River at the most upstream site near Pinedale (NF1) was around $50 \mathrm{ft}^{3} / \mathrm{s}$ and generally increased at each downstream site with around $350 \mathrm{ft}^{3} / \mathrm{s}$ measured as the largest streamflow in the river at NF8 (table 2; fig. 4). Major tributaries to the New Fork River in this section include Pine Creek, Pole Creek, Boulder Creek, and East Fork River.

Streamflow measured in the New Fork River during October 19-22, 2015, was compared to the mean daily flow for October 20 during the period of record at the two sites, NF4 and NF8, where long-term data have been collected (fig. 4). The mean streamflow during the October 2015 synoptic measurements at site NF4 was $206 \mathrm{ft}^{3} / \mathrm{s}$, which was within the range of mean daily streamflows collected during 1914-68 and was larger than the median of the 55 years of mean daily streamflow for October 20, which is $154 \mathrm{ft}^{3} / \mathrm{s}$ (fig. 4). The mean streamflow during the October 2015 synoptic measurements at site NF8 was $344 \mathrm{ft}^{3} / \mathrm{s}$, which was within the range of mean daily streamflows collected during 1953-2015, and nearly equal to the median of the 63 years of mean daily streamflow for October 20, which is $337 \mathrm{ft}^{3} / \mathrm{s}$ (fig. 4). 


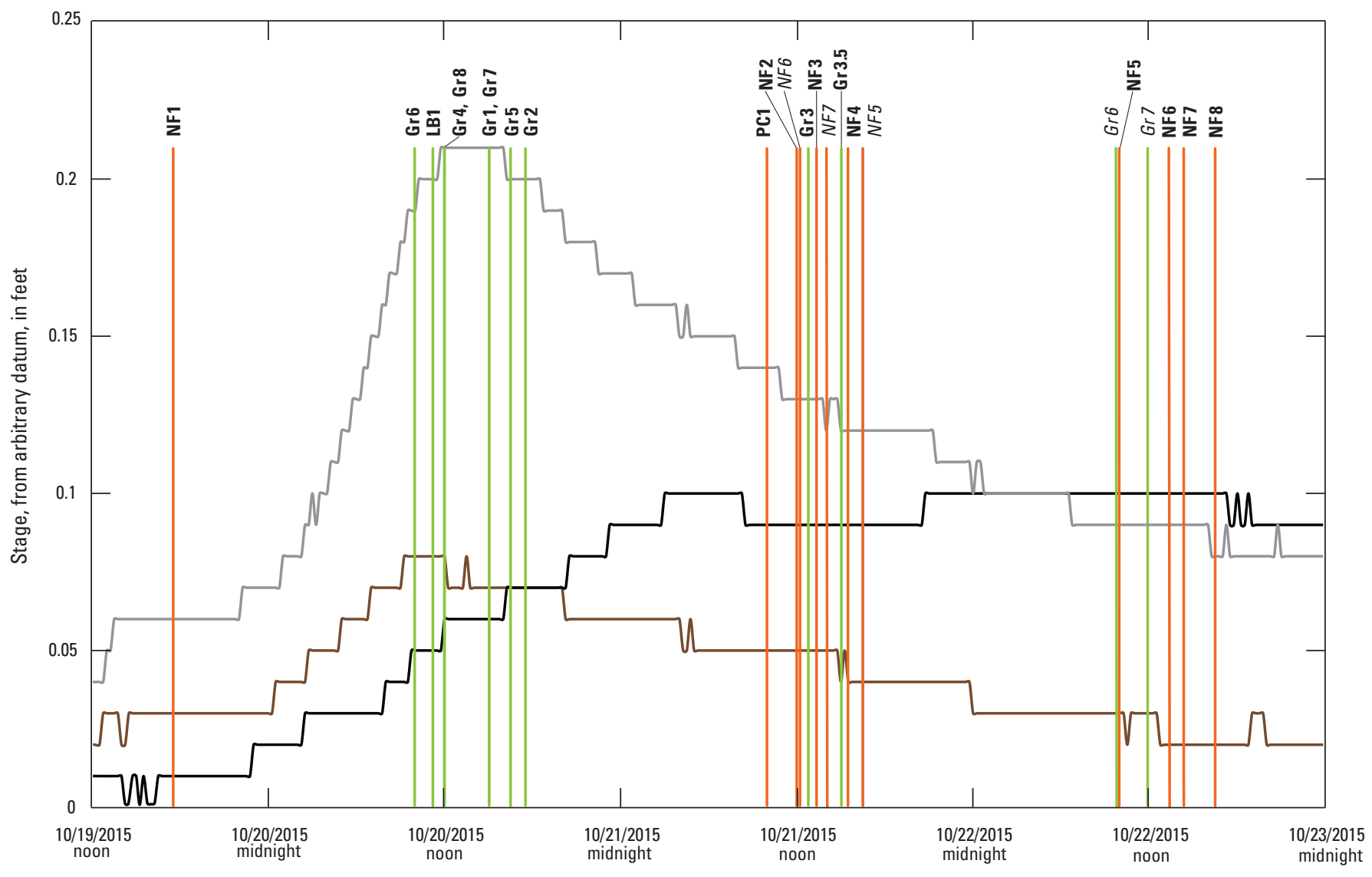

Date and time of instantaneous streamflow measurement at indicated site

\section{EXPLANATION}

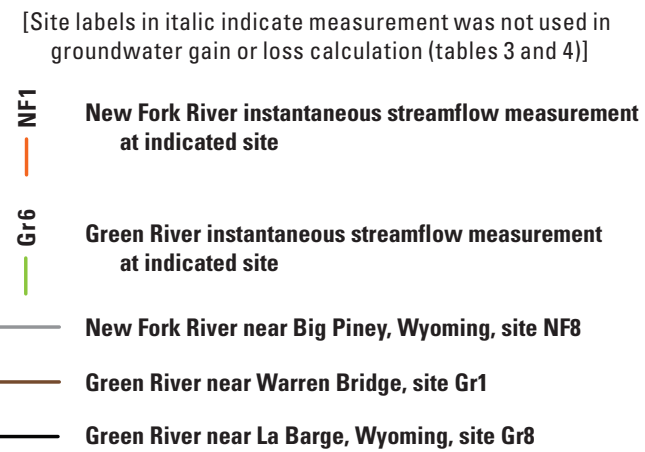

Figure 3. Changes in stage, compared to an arbitrary datum, for streamgages 09205000 (site NF8, New Fork River near Big Piney), 09188500 (site Gr1, Green River at Warren Bridge), and 09209400 (site Gr8, Green River near La Barge) and measurement times of synoptic sampling, Wyoming, October 2015. 
Table 2. Selected streamflow measurements collected on New Fork and Green Rivers, Wyoming, October 19-22, 2015.

$\left[\mathrm{mm} / \mathrm{dd} / \mathrm{yyyy}\right.$, month, day, year; hh:mm, hour:minute; $\mathrm{ft}^{3} / \mathrm{s}$, cubic foot per second; (G), good streamflow measurement quality (less than 5-percent error); (F), fair streamflow measurement quality (5- to 8-percent error); --, not applicable]

\begin{tabular}{|c|c|c|c|c|c|}
\hline $\begin{array}{l}\text { Site number } \\
\text { (fig. 1) }\end{array}$ & $\begin{array}{l}\text { Date and mean time } \\
\text { (mm/dd/yyyy hh:mm) }\end{array}$ & $\begin{array}{c}\text { Streamflow measurements } \\
\text { on main stem } \\
\left(\mathrm{ft}^{\mathrm{t}} / \mathrm{s}\right)\end{array}$ & $\begin{array}{c}\text { Mean main-stem } \\
\text { streamflow } \\
\left(\mathrm{ft}^{3} / \mathbf{s}\right)\end{array}$ & $\begin{array}{c}\text { Streamflow } \\
\text { measurements } \\
\text { on tributary } \\
\left(\mathrm{ft}^{3} / \mathrm{s}\right)\end{array}$ & $\begin{array}{c}\text { Mean tributary } \\
\text { streamflow } \\
\left(\mathrm{ft}^{3} / \mathrm{s}\right)\end{array}$ \\
\hline \multicolumn{6}{|c|}{ New Fork River sites } \\
\hline NF1 & 10/19/2015 18:00 & $49.1(\mathrm{G}), 48.7(\mathrm{~F}), 49.4(\mathrm{G})$ & 49.1 & -- & -- \\
\hline NF2 & 10/21/2015 11:00 & $95.4(\mathrm{G}), 95.6(\mathrm{G})$ & 95.5 & -- & -- \\
\hline $\mathrm{PC} 1$ & 10/21/2015 10:00 & -- & -- & $\begin{array}{l}54.0(\mathrm{~F}), 60.2(\mathrm{~F}), \\
56.9(\mathrm{~F}), 61.6(\mathrm{~F})\end{array}$ & 58.2 \\
\hline NF3 & 10/21/2015 13:20 & $191(\mathrm{G}), 184(\mathrm{G})$ & 188 & -- & -- \\
\hline NF4 & $10 / 21 / 201515: 25$ & 207(G), 204(G) & 206 & -- & -- \\
\hline NF5 & 10/22/2015 10:00 & 281(F), 296(F),289(F), 301(F) & 292 & -- & -- \\
\hline NF6 & 10/22/2015 13:15 & $326(\mathrm{G}), 323(\mathrm{G})$ & 325 & -- & -- \\
\hline NF7 & $10 / 22 / 201514: 20$ & $352(\mathrm{G}), 359(\mathrm{G})$ & 356 & -- & -- \\
\hline NF8 & $10 / 22 / 201516: 30$ & 333(F), 359(F) & 344 & -- & -- \\
\hline \multicolumn{6}{|c|}{ Green River sites } \\
\hline Gr1 & 10/20/2015 15:00 & 237(F), 258(F), 253(F), 253(F) & 250 & -- & -- \\
\hline Gr2 & 10/20/2015 17:35 & $172(\mathrm{~F}), 172(\mathrm{~F})$ & 172 & -- & -- \\
\hline Gr3 & 10/21/2015 12:45 & $287(\mathrm{G}), 287(\mathrm{G})$ & 287 & -- & -- \\
\hline Gr3.5 & 10/21/2015 15:05 & 329(F), 331(F) & 330 & -- & -- \\
\hline Gr4 & 10/20/2015 12:30 & $321(\mathrm{G}), 316(\mathrm{G}), 289(\mathrm{G})$ & 312 & -- & -- \\
\hline Gr5 & 10/20/2015 16:20 & $722(\mathrm{G}), 711(\mathrm{G})$ & 716 & -- & -- \\
\hline Gr6 & 10/20/2015 10:15 & $770(\mathrm{G}), 768(\mathrm{G})$ & 769 & -- & -- \\
\hline Gr7 & 10/20/2015 15:10 & $681(\mathrm{G}), 692(\mathrm{G})$ & 687 & -- & -- \\
\hline LB1 & 10/20/2015 11:15 & -- & -- & $61.9(\mathrm{~F}), 62.2(\mathrm{~F})$ & 62.1 \\
\hline Gr8 & 10/20/2015 12:10 & $780(\mathrm{G}), 787(\mathrm{G})$ & 784 & -- & -- \\
\hline
\end{tabular}
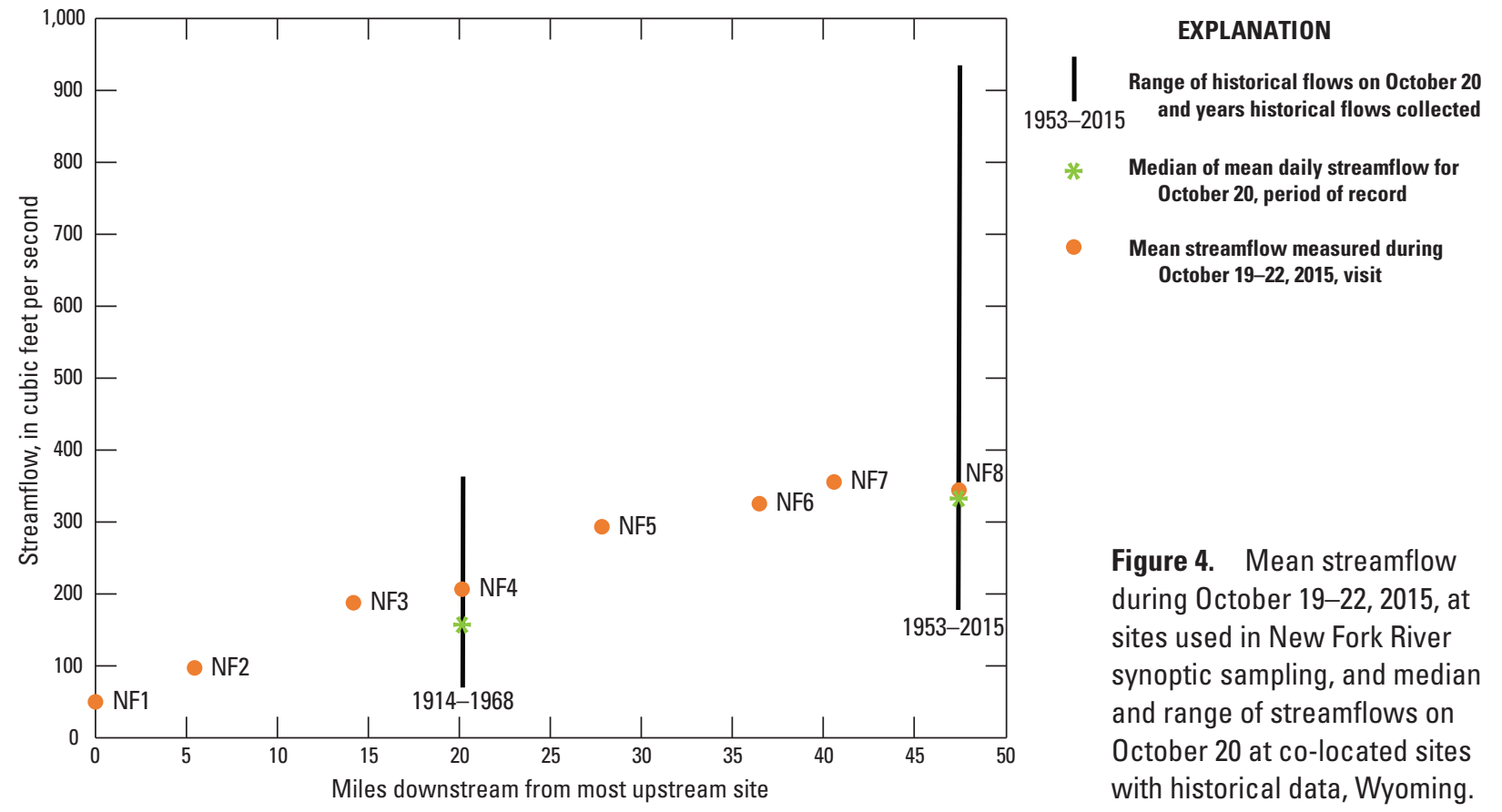

Figure 4. Mean streamflow during October 19-22, 2015, at sites used in New Fork River synoptic sampling, and median and range of streamflows on October 20 at co-located sites with historical data, Wyoming. 


\section{Green River}

Mean streamflow in the Green River during October 19-22, 2015, at the most upstream site at Warren Bridge (Gr1) was $250 \mathrm{ft}^{3} / \mathrm{s}$ (table 2; fig. 5). Mean streamflows at the next two sites, Gr2 and Gr3, had a decrease and then increase in streamflow (172 and $287 \mathrm{ft}^{3} / \mathrm{s}$, respectively). Mean streamflow at site $\mathrm{Gr} 4\left(312 \mathrm{ft}^{3} / \mathrm{s}\right)$ was similar to streamflow at site Gr3. Streamflow at site $\mathrm{Gr} 5\left(716 \mathrm{ft}^{3} / \mathrm{s}\right)$ greatly increased because of the input of the tributary, New Fork River, and streamflow remained between 687 and $784 \mathrm{ft}^{3} / \mathrm{s}$ downstream to site Gr8.

Streamflow measured in the Green River during October 19-22, 2015, was compared to the mean daily flow for October 20 during the period of record at three sites (Gr1, Gr4, and Gr8), where long-term data have been collected (fig. 5). The mean streamflow during the October 2015 synoptic measurements at site $\mathrm{Gr} 1$ was $250 \mathrm{ft}^{3} / \mathrm{s}$, which was within the range of mean daily streamflows collected during 1931-2015 and was larger than the median of the 85 years of mean daily streamflow for October 20, which was $171 \mathrm{ft}^{3} / \mathrm{s}$ (fig. 5). The mean streamflow during the October 2015 synoptic measurements at site $\mathrm{Gr} 4$ was $312 \mathrm{ft}^{3} / \mathrm{s}$ and is within the range of instantaneous streamflow measurements collected during water-quality sampling nearest to October 20 at the site from 1967 to 1984, and similar to the median streamflow during those 17 sampling events, which was $307 \mathrm{ft}^{3} / \mathrm{s}$ (fig. 5). The mean streamflow during the October 2015 synoptic measurements at site Gr8 was $784 \mathrm{ft}^{3} / \mathrm{s}$, which was within the range of mean daily streamflows on October 20 collected during 1963-2015, and slightly larger than the median of the 33 years of mean daily streamflow for that date, which was $737 \mathrm{ft}^{3} / \mathrm{s}$ (fig. 5).

\section{Estimated Streamflow Gains and Losses in Selected River Reaches of the New Fork and Green Rivers}

Streamflow gains and losses attributed to groundwater were determined for five reaches on the New Fork River and four reaches on the Green River using the mean streamflow and associated error for each set of synoptic measurements. Streamflow gains and losses for each reach were calculated by subtracting the streamflow at the most upstream site and any tributary inflows from the most downstream site.

A level of uncertainty or measurement error is associated with every streamflow measurement, including those made during this investigation. This uncertainty, also known as measurement error, standard error, or indeterminate error, results from inherent inaccuracies associated with the equipment and techniques used during each individual streamflow measurement. The source of these uncertainties in U.S. Geological Survey streamflow measurements have been analyzed and a rating system has been developed to estimate this measurement error of individual streamflow measurements (Sauer and Meyer, 1992). This rating system was used in this study to estimate measurement error for each streamflow measurement as follows: good (measured streamflow within 5 percent of the actual streamflow [ 5 percent used for calculations in this report]); fair (between 5 and 8 percent [8 percent used for calculations in this report]); and poor (measured streamflow 8 percent greater or less than the actual streamflow [no poor measurements were collected during this study]). The measurement error associated with a calculated streamflow gain or loss attributed to groundwater is a function of the

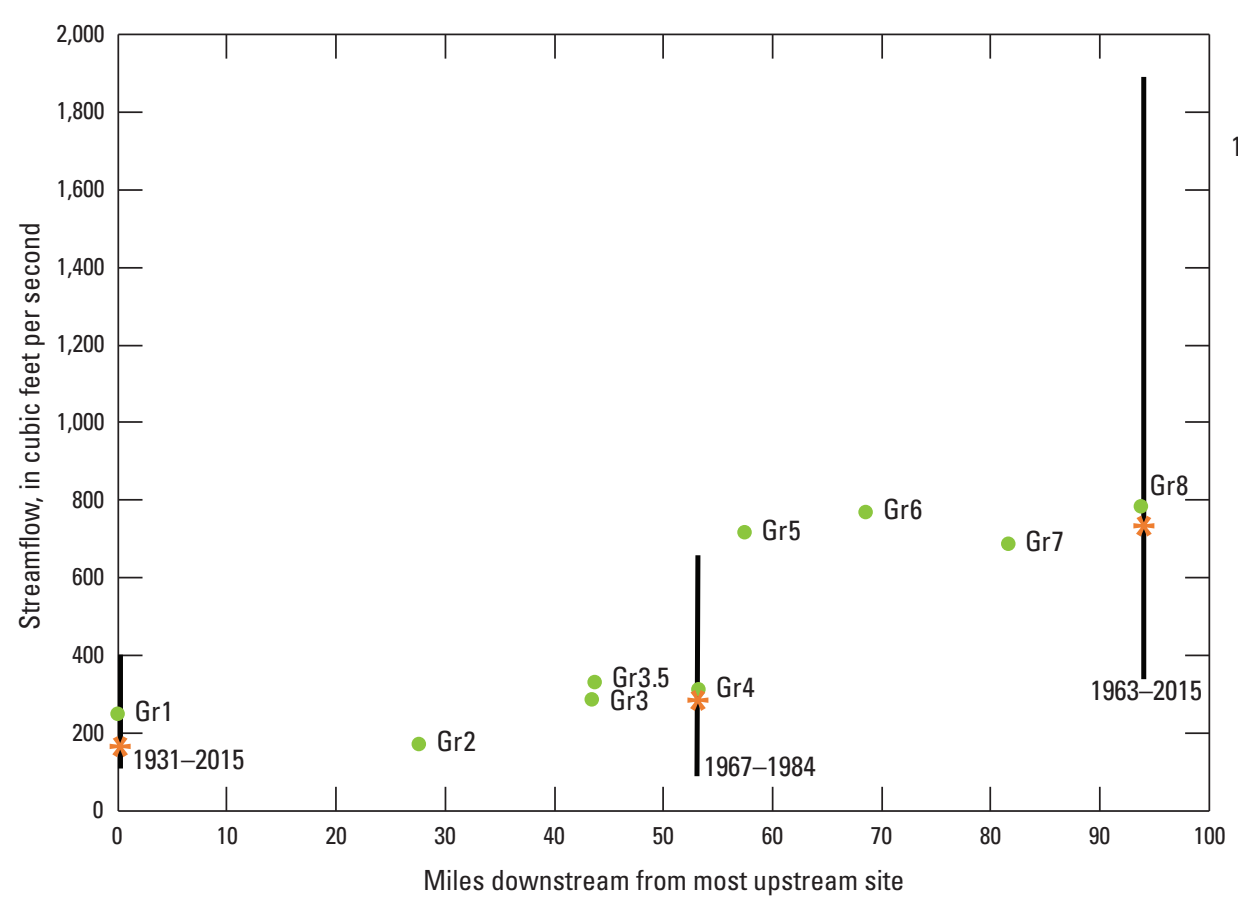

\section{EXPLANATION}

| $\begin{array}{r}\text { Range of historical flows on } 0 \text { ctober } 20 \\ \text { and years historical flows collected }\end{array}$

* Median of mean daily streamflow for October 20, period of record

- Mean streamflow measured during October 19-22, 2015, visit

Figure 5. Mean streamflow during October 19-22, 2015, at sites used in Green River synoptic sampling, and median and range of streamflows on October 20 (or the month of October for site $\mathrm{Gr} 4$ ) at co-located sites with historical data, Wyoming. 
measurement errors from all streamflow measurements used to calculate that loss or gain.

The computed value of each groundwater gain or loss has an associated estimated measurement error. This estimated error was calculated by using equation 1 , the propagation of error formula (Helsel and Hirsch, 1992):

$$
S=\sqrt{( \pm a)^{2}+( \pm b)^{2}+\ldots+( \pm n)^{2}}
$$

where

$$
\begin{aligned}
& s \quad \text { is the error propagated from all estimated } \\
& \text { individual errors, and } \\
& a, b, \ldots, n \quad \text { are the estimated errors for the median } \\
& \text { streamflow measurement at each site. }
\end{aligned}
$$

Estimated measurement accuracy ranged from about 3- to 5-percent error at most sites to 8-percent error at sites with low streamflow, uneven channel characteristics, and (or) considerable aquatic growth.

\section{New Fork River}

Streamflow gains and losses were estimated for five reaches on the New Fork River (table 3). All reaches that had a change greater than the associated measurement error were gaining reaches. Reach 1 had the highest estimated gain from groundwater as can be noted by the difference of the streamflow measurement at sites NF3 compared to the inflows of the streamflow of NF2 plus PC1 (fig. 6). The additional streamflow measured at NF3 is likely because of inflow of groundwater recharged from irrigation, canal seepage, or infiltration of lake water along the moraines generally north of the river in that reach (fig. 1). Estimated streamflow in reach 2 also gained water from groundwater to a smaller extent than reach 1 , likely from the same sources.

Calculations for reaches 3 and 4 determined streamflow gains in both reaches were greater than the estimated errors (table 3). Groundwater gains in these reaches are likely

\begin{tabular}{|c|c|c|c|c|c|}
\hline $\begin{array}{l}\text { Site number } \\
\text { or reach } \\
\text { (fig. 2) }\end{array}$ & $\begin{array}{c}\text { Mean } \\
\text { streamflow } \\
\left(\mathrm{ft}^{3} / \mathbf{s}\right)\end{array}$ & $\begin{array}{l}\text { Mean tributary } \\
\text { streamflow } \\
\left(\mathrm{ft}^{3} / \mathbf{s}\right)\end{array}$ & $\begin{array}{c}\text { Estimated } \\
\text { measurement } \\
\text { error } \\
\left( \pm f t^{3} / \mathbf{s}\right) \\
\end{array}$ & $\begin{array}{c}\text { Streamflow gain }(+) \text { or loss }(-) \\
\text { attributed to groundwater and } \\
\text { associated measurement error } \\
\qquad\left(\mathrm{ft}^{\mathrm{t}} / \mathrm{s}\right)^{1}\end{array}$ & Remarks \\
\hline \multicolumn{6}{|c|}{ Reach 1} \\
\hline NF2 & 95.5 & -- & 4.8 & -- & -- \\
\hline $\mathrm{PC} 1$ & -- & 58.2 & 4.7 & -- & -- \\
\hline NF3 & 188 & & 9.4 & -- & -- \\
\hline Reach 1 & -- & -- & -- & $33.8 \pm 11.5$ & Gaining reach. \\
\hline \multicolumn{6}{|c|}{ Reach 2} \\
\hline NF3 & 188 & -- & 9.4 & -- & -- \\
\hline NF4 & 206 & -- & 10.3 & -- & -- \\
\hline Reach 2 & -- & -- & -- & $18.0 \pm 13.9$ & Gaining reach. \\
\hline \multicolumn{6}{|c|}{ Reach 3} \\
\hline NF5 & 292 & -- & 23.3 & -- & -- \\
\hline NF6 & 325 & -- & 16.2 & -- & -- \\
\hline Reach 3 & -- & -- & -- & $32.8 \pm 28.4$ & Gaining reach. \\
\hline \multicolumn{6}{|c|}{ Reach 4} \\
\hline NF6 & 325 & -- & 16.2 & -- & -- \\
\hline NF7 & 356 & -- & 17.8 & -- & -- \\
\hline Reach 4 & -- & -- & -- & $31.0 \pm 24.1$ & Gaining reach. \\
\hline \multicolumn{6}{|c|}{ Reach 5} \\
\hline NF7 & 356 & -- & 17.8 & -- & -- \\
\hline NF8 & 344 & -- & 27.5 & -- & -- \\
\hline Reach 5 & -- & -- & -- & $-12.0 \pm 32.7$ & $\begin{array}{l}\text { Difference in measured stream- } \\
\text { flow is less than the associated } \\
\text { measurement error. }\end{array}$ \\
\hline
\end{tabular}
because of recently recharged groundwater from infiltration

Table 3. Mean streamflow measured, estimated errors, and streamflow gains and (or) losses estimated for New Fork River reaches, Wyoming, October 19-22, 2015.

[ft $\mathrm{ft}^{3} / \mathrm{s}$, cubic foot per second; \pm , plus or minus; --, not applicable or no remarks]

${ }^{1}$ Gains and losses may not exactly compute due to streamflow measurement rounding. 
of irrigated fields and unlined canals. Applied irrigation water likely maintains higher streamflows in the fall from groundwater continuing to return to the stream as can be seen in figure 7 . By comparison, there is only one irrigation diversion upstream from Green River at Warren Bridge; thus, the site represents relatively natural hydrologic conditions, and the mean daily streamflow begins to taper off in September and reaches base-flow conditions in early November (fig. 7). Mean daily streamflow at New Fork near Big Piney streamgage, however, shows sustained and elevated flow through late November before declining to base-flow conditions. The calculated streamflow gain or loss for reach 5 was less than the estimated error associated with the measurements.
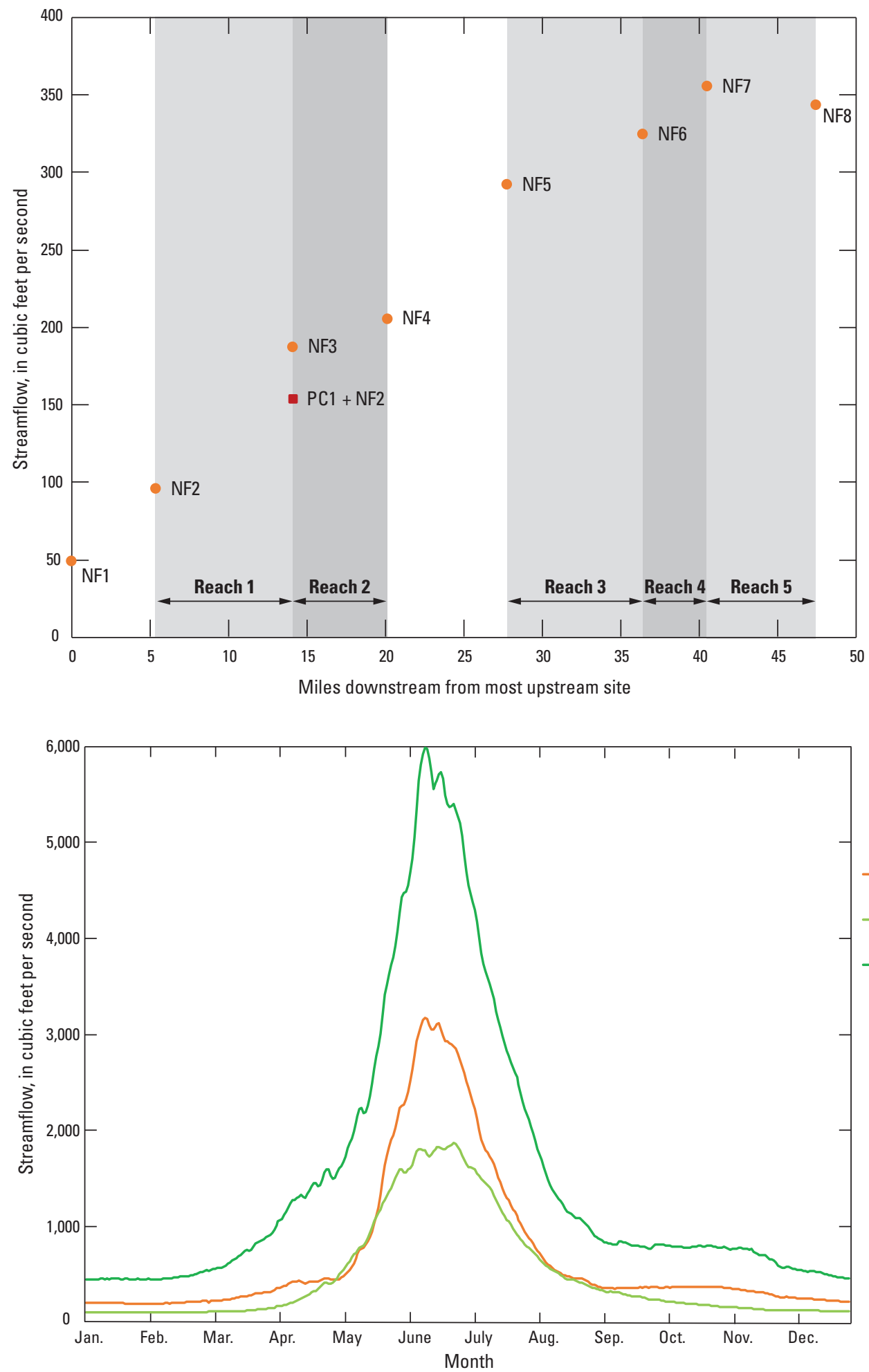

\section{EXPLANATION}

Mean streamflow measured during October 19-22, 2015, visit

Summation of measured upstream streamflows
Figure 6. Mean streamflow measured during 0ctober 19-22, 2015, synoptic measurements and summation of measured upstream inflows, New Fork River, Wyoming.

\section{EXPLANATION}

Mean of mean daily streamflow during period of record noted

New Fork River near Big Piney, Wyoming, 1954-2015

Green River at Warren Bridge, near Daniel, Wyoming, 1931-2015

Green River River near La Barge, Wyoming, 1963-2015

Figure 7. Mean of mean daily streamflow for the period of record at streamgages 09205000 (site NF8, New Fork River near Big Piney), 09188500 (site Gr1, Green River at Warren Bridge), and 09209400 (site Gr8, Green River near La Barge), Wyoming. 


\section{Green River}

Estimated streamflow gains and losses were calculated for four reaches on the Green River (table 4). One reach was determined to be a gaining reach, one a losing reach, and two had changes less than the associated measurement error. The Green River reach 6 (fig. 8) begins immediately downstream from Cottonwood Creek, and although there are numerous historical channels that had water in them and there was likely dispersed groundwater inflow from irrigation return flow, the change in streamflow along the reach was less that the associated measurement errors.

Calculations of gains or losses in reach 7, which is the reach where inflows from the New Fork River (considered a tributary) join the Green River, indicate the stream is gaining in this reach. The downstream end of reach 7 is a topographic and geologic pinch point and the location where groundwater flow would likely move from dispersed flow in the alluvial aquifer into the stream. Sources of groundwater are likely recently recharged irrigation or overland flows during spring snowmelt, and potentially, to a smaller extent, deeper groundwater.

Calculations of gains or losses indicate that reach 8 is a losing reach, and streamflow leaves the river, likely to near-stream groundwater. This reach also overlies the lower Tertiary aquifer system described in Bartos and others (2015), and although the pressure gradient indicates groundwater in the lower Tertiary aquifers flows to the Green River in this area, it seems that the influence on streamflow is negligible, likely because of either the low transmissivity of the units or a small pressure gradient. Reach 9, the final reach of the Green River described, had no gain or loss that was greater than the associated estimated measurement error.

Table 4. Mean streamflow measured, estimated errors, and gain or loss calculations for Green River reaches, Wyoming, October 19-22, 2015.

[ $\mathrm{ft}^{3} / \mathrm{s}$, cubic foot per second; \pm , plus or minus; --, not applicable or no remarks]

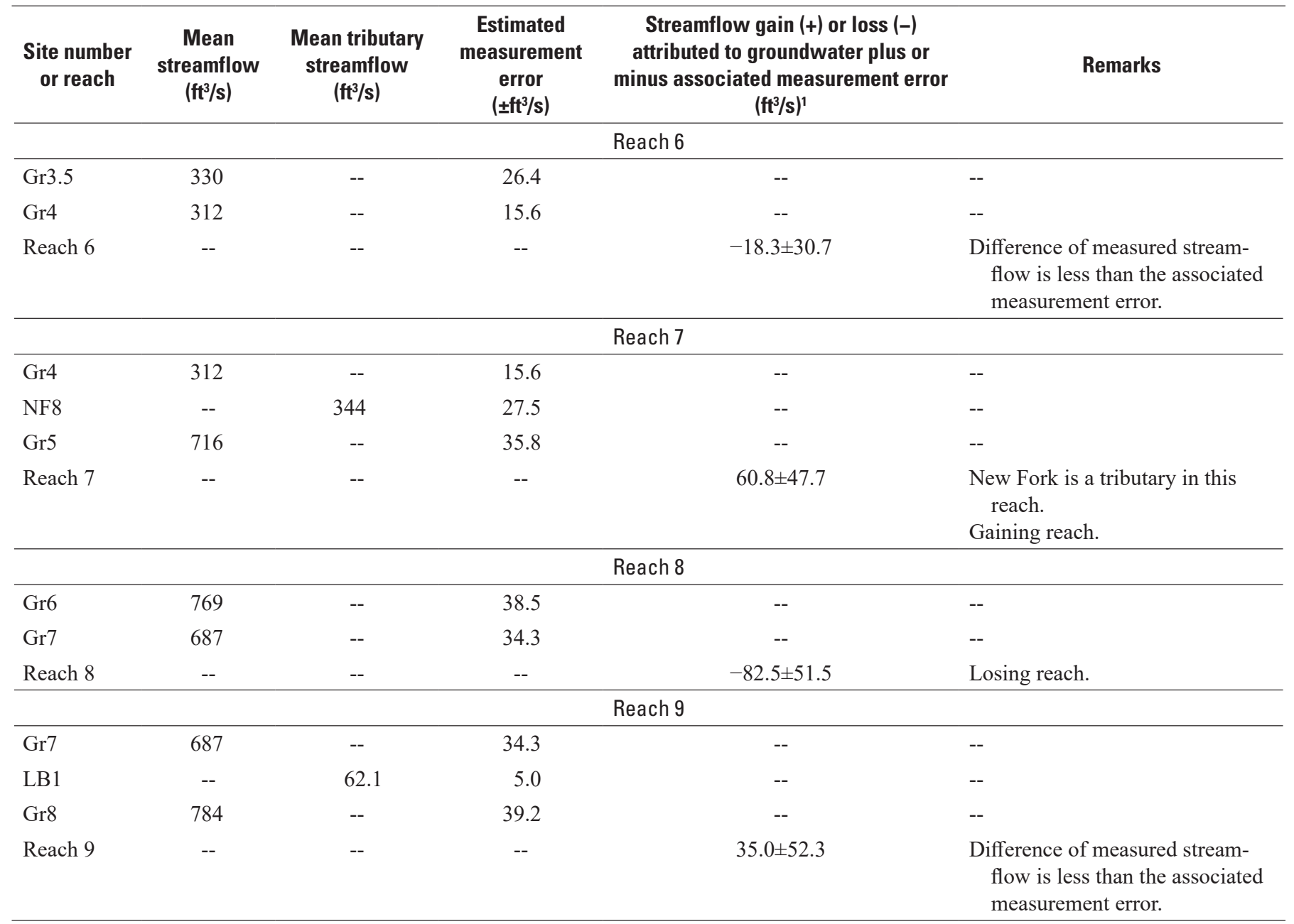

\footnotetext{
${ }^{1}$ Gains and losses may not exactly compute due to streamflow measurement rounding.
} 


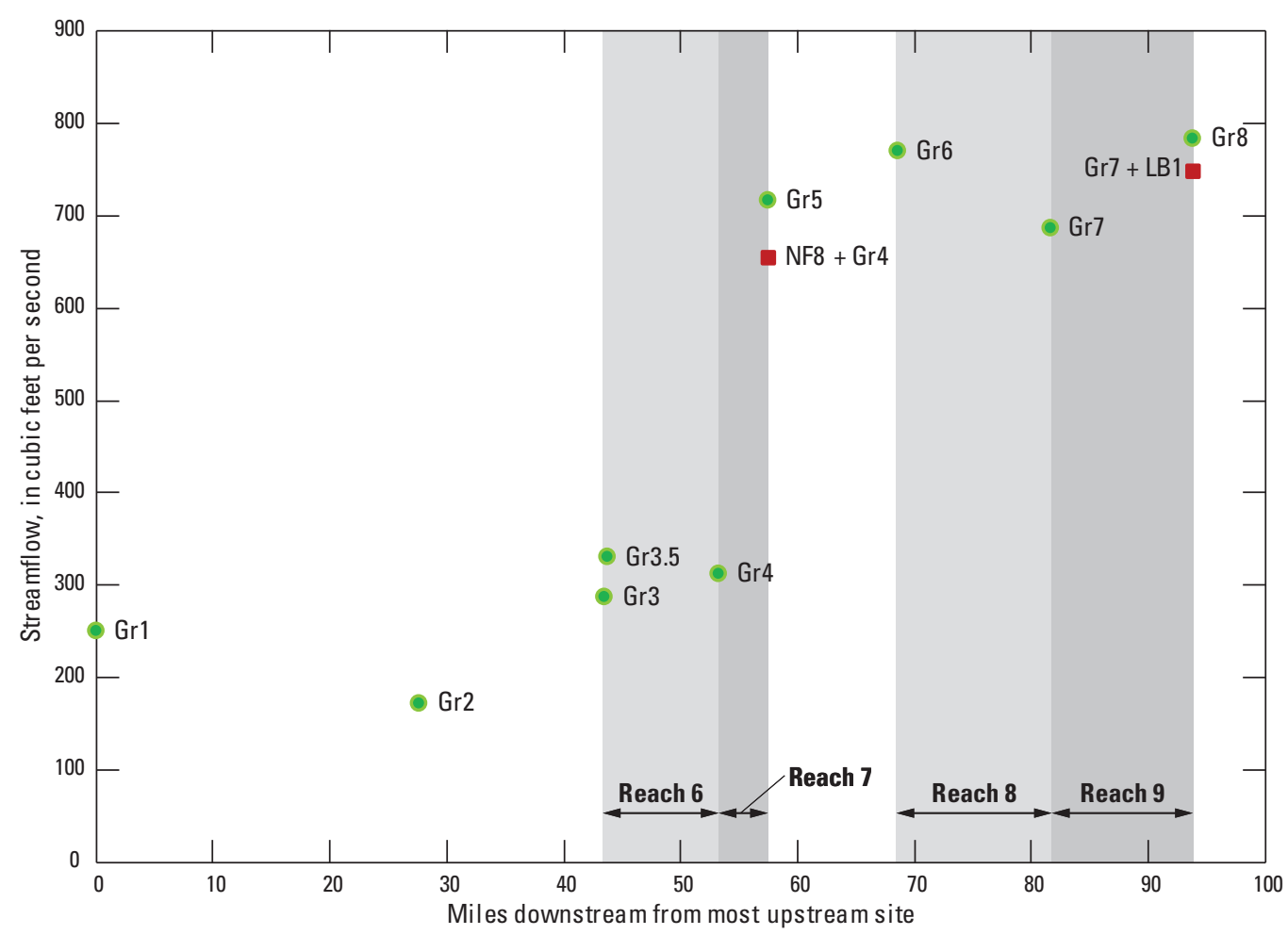

EXPLANATION

Mean streamflow measured during October 19-22, 2015, visit

Summation of measured upstream streamflow
Figure 8. Mean streamflow measured during October 19-22, 2015, synoptic measurements and summation of measured upstream inflows, Green River, Wyoming.
The annual streamflow hydrograph (fig. 7) of Green River near La Barge also shows likely effects of applying irrigation water to land draining to the Green River. Streamflows in Green River near La Barge are sustained later in the season compared to the upstream Green River at Warren Bridge site, which has few diversions and minimal irrigation.

\section{Summary}

The Wyoming Landscape Conservation Initiative is a program created to implement a long-term, science-based program of assessing natural resources while facilitating responsible energy and other development and has studies in much of southwestern Wyoming, including all or parts of Lincoln, Sublette, Fremont, Sweetwater, and Carbon Counties. To better understand the streamflow dynamics in the New Fork and Green Rivers, which flow through an area with historical, current, and future energy development, a synoptic streamflow measurement study was completed by the U.S. Geological Survey in cooperation with the Bureau of Land Management as part of ongoing contributions to the Wyoming Landscape Conservation Initiative.

The New Fork and Green Rivers originate in Wyoming in the Wind River Range with snowmelt as the primary water source. Both rivers are perennial from their headwaters, flowing through high elevation lakes before entering the basin proper. The rivers generally flow south and meet about halfway through the study area. Many irrigation diversions and return flows exist on the New Fork and Green Rivers. Unused and infiltrated irrigation water returns to both rivers through discrete canals, dispersed surface expressions, and movement through the subsurface.

A total of 46 streamflow measurements were collected October 19-22, 2015, at 19 sites on the New Fork and Green Rivers to determine changes in streamflow and, where applicable, describe the inflow and outflow of groundwater. At least two streamflow measurements were performed during each visit, either concurrently or sequentially, to increase the accuracy of the streamflow value.

Streamflow in the New Fork River generally increased downstream from 50 cubic feet per second $\left(\mathrm{ft}^{3} / \mathrm{s}\right)$ at the most upstream site near Pinedale to $350 \mathrm{ft}^{3} / \mathrm{s}$ at the mouth of the river. Streamflow in the Green River generally increased downstream from $250 \mathrm{ft}^{3} / \mathrm{s}$ at the most upstream site at Warren Bridge to $800 \mathrm{ft}^{3} / \mathrm{s}$ at the most downstream to site near La Barge, above Fontenelle Reservoir.

Estimated streamflow gains and losses were calculated for five reaches on the New Fork River. Four of the five reaches on the New Fork River had a change greater than the associated measurement error and were gaining reaches; the reach with the largest gain was in the most upstream reach. One reach, the most downstream reach, had a calculated change in streamflow less than the associated measurement error. 
Estimated streamflow gains and losses were calculated for four reaches on the Green River. One reach was determined to be a gaining reach, one was a losing reach, and two reaches had changes less than the associated measurement error.

Comparison of the annual streamflow hydrographs for three long-term streamgages likely showed the effects of applying irrigation water to land draining to the Green and New Fork Rivers. Streamflows in the New Fork River near Big Piney and the Green River near La Barge are sustained later in the season compared to the upstream site, Green River at Warren Bridge, which has few diversions and minimal irrigation.

\section{References Cited}

Bartos, T.T., Hallberg, L.L., and Eddy-Miller, C.A., 2015, Hydrogeology, groundwater levels, and generalized potentiometric-surface map of the Green River Basin lower Tertiary aquifer system, 2010-14, in the northern Green River structural basin, Wyoming: U.S. Geological Survey Scientific Investigations Report 2015-5090, 33 p., accessed December 20, 2018, at https://doi.org/10.3133/sir20155090.

Bowen, Z.H., Aldridge, C.L., Anderson, P.J., Assal, T.J., Bern, C.R., Biewick, L.R.H., Boughton, G.K., Carr, N.B., Chalfoun, A.D., Chong, G.W., Clark, M.L., Fedy, B.C., Foster, K., Garman, S.L., Germaine, S., Hethcoat, M.G., Homer, C., Kauffman, M.J., Keinath, D., Latysh, N., Manier, D., McDougal, R.R., Melcher, C.P., Miller, K.A., Montag, J., Potter, C.J., Schell, S., Shafer, S.L., Smith, D.B., Sweat, M.J., and Wilson, A.B., 2014, U.S. Geological Survey science for the Wyoming Landscape Conservation Initiative-2012 annual report: U.S. Geological Survey OpenFile Report 2014-1093, 71 p., accessed February 28, 2017, at https://doi.org/10.3133/ofr20141093.
Helsel, D.R., and Hirsch, R.M., 1992, Statistical methods in water resources: New York, Elsevier Science Publishing Company, Inc., 522 p.

Love, J.D., and Christiansen, A.C., comps., 1985, Geologic map of Wyoming: U.S. Geological Survey map, 3 sheets, scale 1:500,000. [Also available at https://doi.org/10.3133/70046739.]

Nolan, K.M., and Shields, R.R., 2000, Measurement of stream discharge by wading: U.S. Geological Survey WaterResources Investigations Report 00-4036, accessed December 20, 2018, at https://doi.org/10.3133/wri20004036.

Rantz, S.E., and others, 1982, Measurement and computation of streamflow: U.S. Geological Survey Water-Supply Paper 2175, 2 vols., 631 p., accessed December 20, 2018, at https://pubs.usgs.gov/wsp/wsp2175/pdf/WSP2175_vol1a. pdf.

Sauer, V.B., and Meyer, R.W., 1992, Determination of error in individual discharge measurements: U.S. Geological Survey Open-File Report 92-144, 21 p., accessed December 20, 2018, at https://doi.org/10.3133/ofr92144.

U.S. Geological Survey, 2019, USGS surface-water data for Wyoming, in USGS water data for the Nation: U.S. Geological Survey National Water Information System database, accessed June 2019 at https://doi.org/10.5066/F7P55KJN. [Wyoming surface-water information directly accessible at https://waterdata.usgs.gov/wy/nwis/sw.] 
For more information about this publication, contact:

Director, USGS Wyoming-Montana Water Science Center

3162 Bozeman Avenue

Helena, MT 59601

406-457-5900

For additional information, visit: https://www.usgs.gov/centers/wy-mt-water/

Publishing support provided by the

Rolla Publishing Service Center 



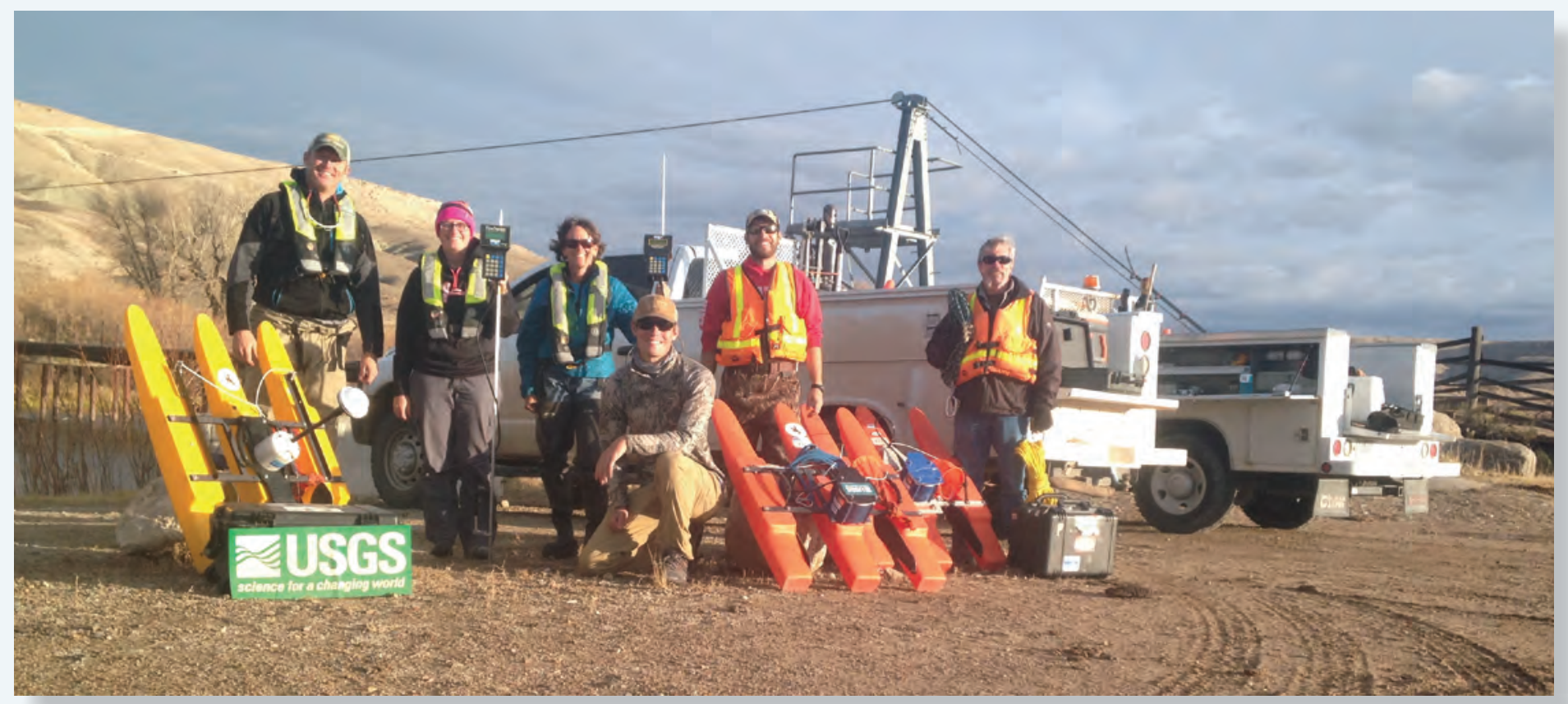

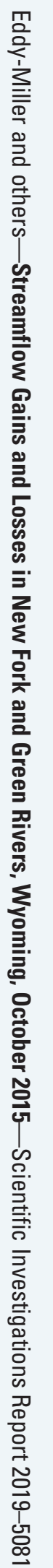

